\title{
Serum vitamin E concentrations are normal in Friedreich's ataxia
}

\author{
D P R MULLER,* S MATTHEWS, ${ }^{*}$ A E HARDING $\dagger$ \\ From the Department of Child Health, Institute of Child Health, Guilford Street, ${ }^{*}$ and the University \\ Department of Clinical Neurology, Institute of Neurology, $\dagger$ London, UK
}

SUMMARY Serum vitamin E concentrations and vitamin E:cholesterol ratios in 31 patients with Friedreich's ataxia were not significantly different from values obtained from either disabled or ambulant control subjects. Although the clinical features of Friedreich's ataxia are similar to those associated with severe vitamin $\mathrm{E}$ deficiency, there are subtle but important clinical and neurophysiological differences between the two disorders.

A progressive neurological disorder comprising limb and gait ataxia, areflexia, and distal loss of proprioception and vibration sense occurs in abetalipoproteinaemia, ${ }^{1}$ and has also been described in association with acquired causes of chronic fat malabsorption such as biliary atresia, cystic fibrosis, and following extensive intestinal resection. ${ }^{2-6}$ There is good evidence that this spinocerebellar syndrome is caused by severe and prolonged deficiency of vitamin E. ${ }^{7}$ More recent reports have described patients with an identical neurological disorder associated with very low or undetectable serum concentrations of vitamin $E$ in the absence of generalised fat malabsorption or hypolipoproteinaemia. ${ }^{8-11}$ It is possible that this apparently selective defect of vitamin $\mathrm{E}$ absorption is genetically determined. ${ }^{11}$

The neurological features of vitamin E deficiency are similar to those seen in Friedreich's ataxia, an autosomal recessive disorder in which no consistent underlying metabolic defect has been identified. ${ }^{12}$ Barbeau and colleagues ${ }^{13}$ reported slightly reduced serum concentrations of vitamin $\mathrm{E}$ in 15 patients with Friedreich's ataxia but these were not significantly different from controls. This paper reports a study of serum vitamin $\mathrm{E}$ concentrations in 31 cases of Friedreich's ataxia, which were compared to those in

Address for reprint requests: Dr Harding, Institute of Neurology, Queen Square, London WCIN 3BG, UK.

Received 31 December 1985 and in revised form 3 April 1986. Accepted 17 April 1986 both able bodied and disabled control subjects. Vitamin E concentrations are also expressed as a proportion of serum cholesterol concentrations, as it has been suggested that this ratio is a more reliable index of vitamin E status. ${ }^{14}$

\section{Patients, methods, and results}

Thirty one patients with Friedreich's ataxia were studied, all of whom fulfilled the diagnostic criteria given by Harding. ${ }^{12}$ Their ages ranged from 8 to 59 years, and 23 of them were either wheelchair dependent or had considerable difficulty in walking. There were two groups of age and sex matched control subjects. The first comprised 31 individuals who were healthy or had neurological disorders which did not give rise to physical disability, and the second group consisted of 23 patients who had long-standing neurological disability of comparable severity to that seen in the 23 disabled cases of Friedreich's ataxia. The majority of these disabled controls had multiple sclerosis; cases of hereditary or degenerative ataxic disorders were excluded. Relatives of patients with Friedreich's ataxia were not used as controls, and none of the individuals studied had knowingly received vitamin $E$ supplements within the last two years.

Vitamin E concentrations were estimated 'blindly' in non-fasting samples of serum using a colorimetric method. ${ }^{15}$ Serum cholesterol concentrations were measured enzymatically. For statistical analysis, the 23 disabled Friedreich's ataxia patients were ran- 

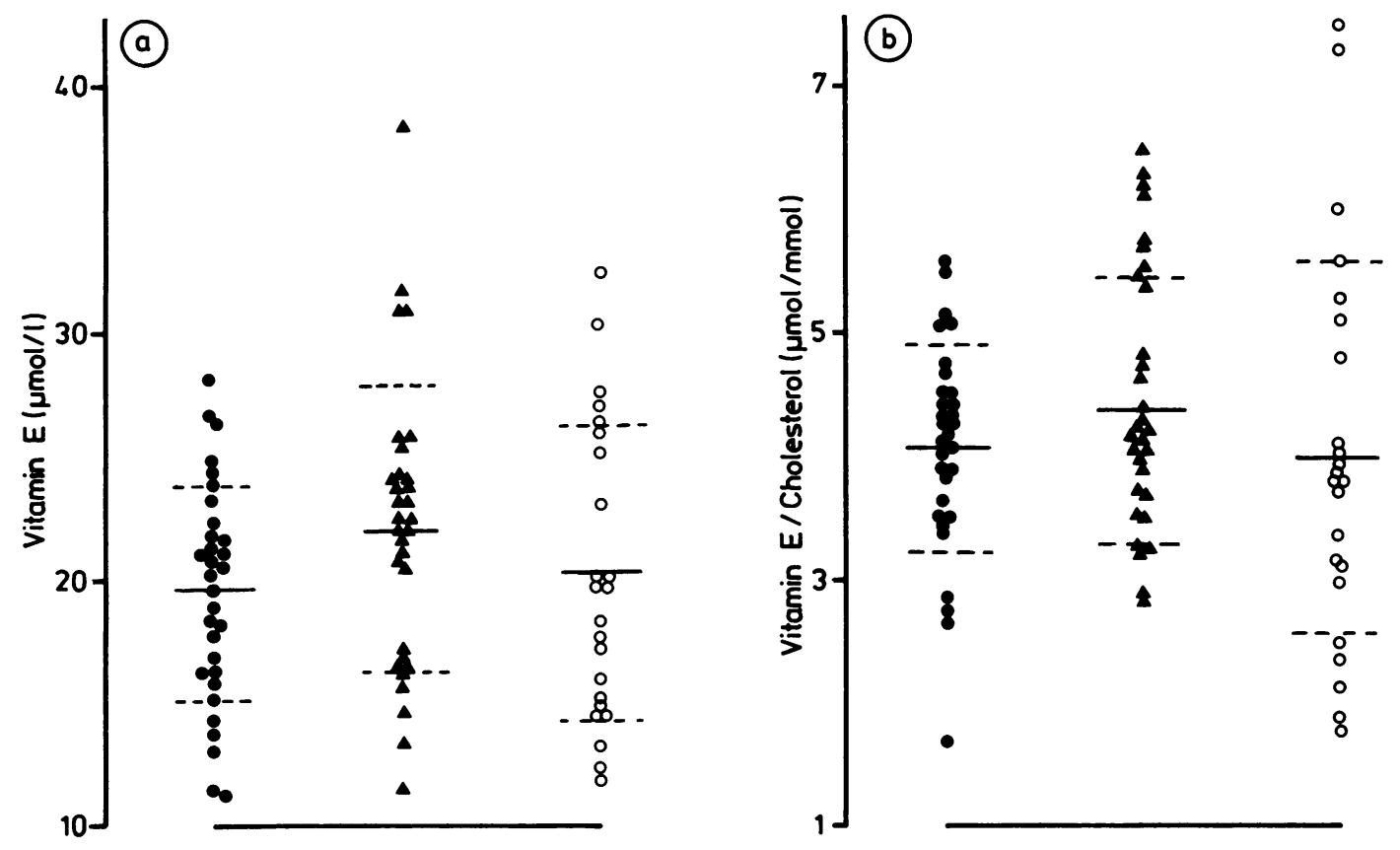

Fig Serum vitamin E concentrations and vitamin E:cholesterol ratios in 31 cases of Friedreich's ataxia (triangles), 31 ambulant (filled circles) and 23 disabled (open circles) control subjects. denotes mean, and - -1 standard deviation.

Table Serum vitamin E and cholesterol concentrations in 31 patients with Friedreich's ataxia and control subjects

\begin{tabular}{|c|c|c|c|c|c|}
\hline \multirow[b]{2}{*}{$\begin{array}{l}\text { Vitamin E }(\mu \mathrm{mol} / \mathrm{l}) \\
\text { Cholesterol }(\mathrm{mmol} / \mathrm{l}) \\
\text { Vitamin E: cholesterol ratio } \\
\quad(\mu \mathrm{mol} / \mathrm{mmol})\end{array}$} & \multicolumn{2}{|c|}{ Ambulant controls $(n=31)$} & \multicolumn{2}{|c|}{$\begin{array}{l}\text { Friedreich's ataxia }(n=3 I) \\
\text { mean }(\text { range })\end{array}$} & \multirow{2}{*}{$\begin{array}{l}\begin{array}{l}\text { Disability matched controls } \\
(n=31)\end{array} \\
\begin{array}{l}19 \cdot 6(12 \cdot 5-32 \cdot 5) \\
5.05(3.28-8.8) \\
4.06(1.81-7.5)\end{array}\end{array}$} \\
\hline & $\begin{array}{l}19 \cdot 7(11 \cdot 4-28 \cdot 2) \\
4 \cdot 89(3 \cdot 26-7 \cdot 25) \\
4 \cdot 10(1 \cdot 73-5 \cdot 58)\end{array}$ & $\begin{array}{r}p>0.05 \\
p>0.3 \\
p>0.2\end{array}$ & $\begin{array}{l}22 \cdot 1(11 \cdot 5-38 \cdot 4) \\
5 \cdot 16(3 \cdot 2-9 \cdot 0) \\
4 \cdot 40(2 \cdot 84-6 \cdot 5)\end{array}$ & $\begin{array}{r}p>0.1 \\
p>0.7 \\
p>0.25\end{array}$ & \\
\hline
\end{tabular}

domly paired with two control subjects without knowledge of the serum vitamin $\mathrm{E}$ concentrations. One was matched for age and sex, and the other for age, sex, and degree of physical disability. The eight patients who were only mildly disabled were paired twice with ambulant age and sex matched controls.

Serum vitamin E concentrations, and vitamin E: cholesterol ratios in the three groups are shown in the figure. These, and the serum cholesterol concentrations, were compared using Student's $t$ test for paired data (table). No significant differences were observed between patients and either disabled or ambulant control subjects.

\section{Discussion}

The neurological disorder associated with vitamin $\mathrm{E}$ deficiency is clinically similar to Friedreich's ataxia, but proprioceptive loss tends to be more prominent in vitamin E deficient patients. There are also important neurophysiological and pathological differences between the two syndromes. "Dying-back" of sensory axons occurs in both Friedreich's ataxia and vitamin E deficiency, but in the latter this appears to affect centrally directed axons preferentially, ${ }^{16}$ and there may be preservation of peripheral sensory nerve conduction in the presence of delayed somatosensory evoked potentials. ${ }^{11}$ Even in young children with Friedreich's ataxia there is always a marked loss of large myelinated fibres in the peripheral nerves, associated with small or absent sensory action potentials. ${ }^{17}$ Degeneration of the spinocerebellar and corticospinal tracts is more marked in Friedreich's ataxia than in vitamin $\mathrm{E}$ deficiency. ${ }^{318}$ 
Our failure to demonstrate a systemic deficiency of vitamin E in Friedreich's ataxia does not exclude the possibility of relative deficiency at a cellular level. This might, for example, result from selective defects of cellular incorporation or utilisation of the vitamin which could be compatible with the pathophysiological differences which exist between Friedreich's ataxia and the neurological syndrome associated with reduced serum concentrations of vitamin $\mathrm{E}$.

We thank the physicians who allowed us to study their patients, and the Friedreich's Ataxia Group for financial support. DPRM thanks Hoffmann-La Roche for their continued interest.

\section{References}

1 Herbert PN, Assmann G, Gotto AM, Fredrickson DS. Familial lipoprotein deficiency. In: Stanbury JB, Wyngaarden JB, Fredrickson DS, Goldstein JL, Brown MS, eds. The Metabolic Basis of Inherited Disease. 5th ed. New York: McGraw Hill, 1983:589-21.

2 Elias E, Muller DPR, Scott J. Spinocerebellar disorders in association with cystic fibrosis or chronic childhood cholestasis and virtually undetectable serum concentrations of vitamin E. Lancet 1981;ii:1319-321.

3 Rosenblum JL, Keating JP, Prensky AI, Nelson JS. A progressive neurologic syndrome in children with chronic liver disease. $N$ Engl J Med 1981;304:503-8.

4 Guggenheim MA, Ringel SP, Silverman A, Grabert BE. Progressive neuromuscular disease in children with chronic cholestasis and vitamin E deficiency: diagnosis and treatment with alpha tocopherol. $J$ Pediatr 1982;100:51-8.

5 Harding AE, Muller DPR, Thomas PK, Willison HJ. Spinocerebellar degeneration secondary to chronic intestinal malabsorption: a vitamin $\mathrm{E}$ deficiency syndrome. Ann Neurol 1982;12:419-24.

6 Willison HJ, Muller DPR, Matthews S, et al. A study of the relationship between neurological function and serum vitamin $\mathrm{E}$ concentrations in patients with cystic fibrosis. $J$ Neurol Neurosurg Psychiatry 1985;48:1097-102.

7 Muller DPR, Lloyd JK, Wolff OH. Vitamin E and neurological function. Lancet 1983;i:225-8.

8 Burck U, Goebel HH, Kuhlendahl HD, Meier C, Goebel KM. Neuromyopathy and vitamin $\mathrm{E}$ deficiency in man. Neuropediatrics 1981;12:267-78.

9 Laplante P, Vanasse M, Michaud J, Geoffroy G, Brochu $P$. A progressive neurological syndrome associated with an isolated vitamin E deficiency. Can J Neurol Sci 1984;11:561-4.

10 Stumpf DA, Sokol R, Bettis D, et al. Clinical picture mimicking Friedreich's ataxia associated with vitamin E deficiency and normal fat absorption. Neurology 1985;35 (suppl 1): 145-6.

11 Harding AE, Matthews S, Jones S, Ellis CJK, Booth IW, Muller DPR. Spinocerebellar degeneration associated with a selective defect of vitamin E absorption. $N$ Engl J Med 1985;313:32-5.

12 Harding AE. The Hereditary Ataxias and Related Disorders. Edinburgh: Churchill Livingstone, 1984.

13 Barbeau A, Melançon SB, Lemieux B, Roy M. Biochemical markers in Friedreich's disease. Ital J Neurol Sci 1984;Supplement 4:13-26.

14 Farrell PM, Levine SL, Murphy MD, Adam AJ. Plasma tocopherol levels and tocopherol-lipid relationships in a normal population of children as opposed to healthy adults. Am J Clin Nutr 1978;31:1720-6.

15 Muller DPR, Harries JT, Lloyd JK. The relative importance of the factors involved in the absorption of vitamin $\mathrm{E}$ in children. Gut 1974;15:966-71.

16 Nelson JS, Fitch CD, Fischer VW, Broun GO, Chou AC. Progressive neuropathologic lesions in vitamin E deficient rhesus monkeys. J Neuropathol Exp Neurol 1981;40:166-86.

17 Ouvrier RA, McLeod JG, Conchin TE. Friedreich's ataxia-early detection and progression of peripheral nerve abnormalities. J Neurol Sci 1982;55:137-45.

18 Lamarche JB, Lemieux B, Lieu HB. The neuropathology of "typical" Friedreich's ataxia in Quebec. Can J Neurol Sci 1984;11:592-600. 